The distribution of fishes on the maps is very clear. Red spots show known occurrences, black spots introductions while grey shading shows the continuous range of native species. The grey shading generally conforms to distributions based on the red spots, filling in the gaps. However in a number of species, the limits of grey shading conform neither to the red spots nor obviously to drainage basins. There is no explanation of how this overall distribution was arrived at but is presumably related to ecological limits for the species and physical barriers. Some form of shading to fill in lakes would have made the background map clearer and perhaps partially address the previous comment.

Identification keys for each family are found at the beginning of each family account. An alternative arrangement is to group all keys together and this is one many field and laboratory biologists would prefer. Fish are wet and slimy and having keys grouped together makes for less page turning or facilitates xeroxing and annotating. The keys work well although the one for distinguishing the Brown and Black bullheads gives diagrams of the supraethmoid shapes without explaining what or where this structure is (and it is not in the Glossary either).

Some other minor points of criticism and comment must be noted. The scientific names lack the author and date, perhaps not of significance to most readers but a nuisance to find for those not familiar with the ichthyological literature. The copy I have lacks paper covers and there is only the briefest of blurbs on the authors whose names are sufficiently common not to lend themselves to easy Googling - more background on the authors is often of interest to readers. The common names of fishes in English and French are on the margin of each page enabling a rapid flip through as a search. However the scientific name is not there (and there is space to add it) which would have been a great convenience. It is necessary to remember to flip back to front as well as front to back since some species are only on one page; this is inescapable in the design. The key to Cottidae is a little confusing as "Key to the freshwater sculpins and marine sculpins

\section{The History of Ornithology in Virginia}

By David W. Johnston. 2003. The University of Virginia Press, Box 400318, Charlottesville, Virginia 22904-4318 USA. 219 pages. $\$ 35.00$ U.S. Cloth.

True to the promise implicit in his title, David Johnston's book is a thorough history of ornithology in Virginia. The first five chapters take us from the Tertiary period 65 million years ago through to an examination of 19th-century reports and collections. Along the way we learn all manner of interesting facts. The abundance of skeletal elements of the extinct Passenger Pigeon show it to have been common in the late Pleistocene over 12,000 years ago, and Rock Ptarmigan, Spruce Grouse and Gray Jay remains indicate a cooler climate at the time. Archaeological research at of the genus Myoxocephalus" as this can be read as being a key to only Myoxocephalus species although Cottus species and freshwater Myoxocephalus are included. The photographs note whether a specimen is fresh or preserved but readers should be warned that preserved here generally means very recent preservation as colour is still retained - museum specimens of any age soon lose the colour; compare the colourful "preserved" northern redbelly dace with the really preserved and brownish deepwater sculpin. A few photographs are not as revealing as one could hope for, the colourful sticklebacks being poorly served in this respect. The Glossary is good, distinguishing such terms as bar, band and stripe although commensial is more commonly spelled commensal and watershed is not a "water body together with all its tributaries" but strictly "an elevated boundary area separating tributaries draining to different river systems", and the subopercular bone does not lie completely above the interopercular but mainly behind it (see www.briancoad.com).

Although books on fishes do tend to separate into those on marine species and those in fresh waters, the Manitoban coastal fauna on Hudson Bay comprises only 27 species (Coad and Reist 2004) and could have been included in the book. The authors do in fact deal with 13 of these species which are found in estuarine and fresh waters also. So another 14 species would have given a complete treatment of the Manitoban fishes.

This book will long stand as the definitive guide to Manitoban freshwater fishes and sets a standard for all subsequent provincial and national books of fish faunas.

\section{Literature Cited}

Coad, B. W., and Reist, J. D. 2004. Annotated List of the Arctic Marine Fishes of Canada. Canadian Manuscript Report of Fisheries and Aquatic Sciences, 2674: iv + 112 pages.

BRIAN W. COAD

Canadian Museum of Nature, PO Box 3443, Station Douglas, Ottawa, Ontario K1P 6P4 Canada

a 1700-year-old Indian midden provided the state's only record of the Ivory-billed Woodpecker. Around 1650, early English settlers were so hungry that at times they ate bluebirds, larks, cardinals and goldfinches and Carolina Parakeets - as well as waterfowl, shorebirds, and upland game birds. When settlers arrived from England about 1590, the Indians were cutting holes in gourds to entice Purple Martins to nest.

The chapters on early observers and naturalists are particularly interesting. Thomas Hariot, a young man selected by Sir Walter Raleigh to be part of the 1585 expedition and settlement, made one of the first attempts to list North American birds, but Johnston tells us that Hariot's list of 111 species has never been found. Fortunately, the paintings of John White, Har- 
iot's fellow expedition member and grandfather of Virginia Dare (the first English child born in America), have survived. White painted 35 species of birds and gave the Algonquian name for 23 of them.

The first naturalists in Virginia were the clergyman and botanist, John Banister, who lived at Bristol Parish from 1678 until he was accidentally killed in 1692, and the Reverend John Clayton (1657-1725), who published information about birds and weather in the world's first scientific journal, Philosophical Transactions of the Royal Society of London; four pages of Clayton's account are reproduced by Johnston. Sadly, although Mark Catesby spent seven years in Virginia, 1712-1719, he was then a botanical collector who had not yet learned to paint birds; from those years he mentioned only 33 bird species. When he returned later for another six years, Catesby spent his time farther south, so that his famous book deals mainly with the Carolinas and rarely makes specific mention of Virginia. In 1787, Thomas Jefferson, 14 years before he became the third president of the United States, made the first attempt to list all the birds of Virginia, adding 34 additional species to the 100 pictured for adjacent regions by Catesby.

Later chapters deal specifically with topics such as the contributions of ornithologists with the Smithsonian Institution and the United States government; conservation and game laws; artist-naturalists; extirpated and introduced bird species; falconry; and regions of ornithological importance describing the observers

\section{All-Weather Hawk Watcher's Field Journal}

By Donald Heintzelman. J. L. Darling Corp. 2614 Pacific Hwy., Tacoma, Washington 98424-1017 USA. 66 pages. U.S. \$7.95 Paper

This handy pocket field notebook, 12 by $17.5 \mathrm{~cm}$., consists of a conservation note, a one-page introduction, a three-page list of the diurnal birds of prey of North and Central America, and 51 pages for field observations. At the top of each page are blanks to

\section{Self-Portrait With Turtles: A Memoir}

By David Carroll. 2004. Houghton Mifflin, 222 Berkeley Street, Boston, Massachusetts USA. 181 pages. U.S. \$23.

David Carroll first saw a Spotted Turtle at the age of eight. He has been enchanted by these amazing creatures ever since.

In this exquisitely written book the author of The Year of the Turtle and Swampwalker's Journal shares his obsession with turtles, nature and art. This basically chronological book is divided into four sections: Early Years, Art School, Middle Years, Later Years. Through these sections we see the development of a consummate naturalist and artist, witness his choice of art school over science and the growth of his teaching and artistic careers. The book concludes with Carroll hunting for turtles on the $50^{\text {th }}$ anniversary of his first discovery of a Spotted Turtle. and the contributions for each. Many famous naturalists worked in or passed through Virginia, among them John James Audubon and Roger Tory Peterson. Peterson, while stationed with the U.S. army at Fort Belvoir, "successfully petitioned the officer-in-charge to reroute the line of march on the drill field to avoid an occupied Horned Lark's nest" (page 121).

Items deserving special commendation are the detailed lists: principal ornithological accomplishments; type specimens from Virginia; local bird lists, 18701926; recent bird lists since 1952; Virginia nature writing, 1817-1998; books since 1965 that mention Virginia's avifauna; Algonquian Indian names of birds; bird banders, 1923-1965; principal collectors of bird specimens; and observers reporting migration records to the U.S. Biological Survey, 1884-1946. Detailed references throughout and a selection of old drawings and more recent photographs add to the interest.

Johnston's scholarly and painstaking research makes this is one of the finest ornithological histories available for any state. There are some weaknesses, such as the lack of a Virginia map and an incomplete and inconsistent index which omits names of some important people. This book is a necessity in every museum and University library in North America, and for any one with an interest in the history of ornithology.

\section{STUART Houston}

863 University Drive, Saskatoon, Saskatchewan S7N 0J8, Canada

fill in for date, time, weather, and location, including GPS coordinates. The special feature is the use of allweather writing paper so that one can write in the rain!

\section{Stuart Houston}

863 University Drive, Saskatoon, Saskatchewan S7N 0J8, Canada

Carroll's memoir overcomes the common pitfall of bogging down in autobiographical trivia. His writing is compelling and thought-provoking: "Consecrated to the God of my parents before my eyes were open, I lived my first eight years in a closed circle of family, relatives, church, and school. I lived in a totally human environment filled with human concerns and considerations. It was a world built by people for people." And yet within three days of his family moving to a new home, Carroll had discovered a wetland and encountered a Spotted Turtle: "With that first turtle I crossed a boundary of greater dimensions than I can ever fully comprehend. I changed lives within a life, worlds within a world."

Although Carroll's passion is turtles, his deep connection with nature will resonate with any avid natu- 